\title{
The mystifying mosaic of Moses: On Pentateuch theory and Biblical spirituality
}

\author{
Author: \\ Christo Lombaard ${ }^{1}$ \\ Affiliation: \\ ${ }^{1}$ Department of Christian \\ Spirituality, University of \\ South Africa, South Africa \\ Note: \\ This article is a further \\ development of an invited \\ guest e-lecture, St. Edward's \\ University, Austin, Texas, \\ USA, 14 October 2010, on \\ the initiative of Dr Kelley \\ Coblentz Bautch, Religious \\ and Theological Studies, \\ St. Edward's University, on \\ the basis of the Society \\ of Biblical Literature's \\ International Cooperation \\ Initiaitive; cf. Coblentz \\ Bautch 2010 or www.sbl- \\ site.org/assets/pdfs/KCB \\ IClvideoconferencing.pdf \\ Correspondence to: \\ Christo Lombaard \\ Email: \\ ChristoLombaard@gmail.com \\ Postal address: \\ PO Box 392, Unisa, Pretoria \\ 0003, South Africa \\ Dates: \\ Received: 27 June 2011 \\ Accepted: 10 Aug. 2011 \\ Published: 25 Oct. 2011 \\ How to cite this article: \\ Lombaard, C., 2011, 'The \\ mystifying mosaic of Moses: \\ On Pentateuch theory \\ and Biblical spirituality', \\ HTS Teologiese Studies/ \\ Theological Studies 67(3), \\ Art. \#1121, 5 pages. http:// \\ dx.doi.org/10.4102/hts. \\ v67i3.1121
}

C) 2011. The Authors. Licensee: AOSIS OpenJournals. This work is licensed under the Creative Commons Attribution License.
In this article, developed for and from a 2010 invited guest e-lecture presented at St. Edward's University, Austin, Texas, unexpected historical and theological parallels between Pentateuch Theory and Biblical Spirituality are indicated. Both have inherent confessional impulses, and have always had those. This is indicated by first describing Pentateuch Theory in these terms, by then providing a graphic model of Biblical Spirituality, and in conclusion by summarising the parallels and the inherent existential dynamics involved in both academic fields.

\section{Now and new}

Writings on spirituality, on the one hand, and on the Bible, on the other hand, evidence an almost bewildering array of directions explored in our time. The more so, when these two fields are combined, reflecting on faith and (or: in, or: from) the Christian Scriptures, or, to put it more generally, reflecting on spirituality and religion (cf. Tolle 2008:19-22). To mention just a few of the works that intend to move away from traditional understandings of the triangle of the GodBible-believer faith relationship (cf. Lombaard 2011a) by conceptualising in a different way these three aspects in their interrelations: the popular 2006 book in France by Comte-Sponville, L'esprit de l'athéisme: introduction à une spiritualité sans Dieu (translated in 2007 as The little book of atheist spirituality) finds a British precursor in Salzberg's 2002 Faith, seeking devotion without deity. The more academic counterparts to such explorations include Bailey's The secular faith controversy (2001, to which his 1998 Implicit religion is an important preparation) and Du Toit and Mason's edited volume, Secular spirituality... (2006). Whereas these thoughts find expression in one way in contextual theology in, for example, Tutu's God is not a Christian (2011), they are related in quite a different way to the Christian Scriptures in, for example, Berlinerblau's The secular Bible (2005). In these and other writings, much that seeks afresh is becoming available, namely as academic, semi-academic and popular literature.

However, to adapt a saying of sociologist Michael Burawoy in his public presentations, much of what is now is not necessarily new. Not always, but often what in public forums and publications, wherever they may lie on the academic-popular continuum, are presented as new are in fact ageold theological questions and insights. A truer characterisation of the situation would therefore be that matters which have for a while been dormant, whilst others have dominated the popular and academic agendas, are pushed to the fore again. A new generation, a changing existentialintellectual framework (paradigm or worldview), and a world with an altered matrix of exchange of cultures and ideas has as one if its corollaries that 'new' religious impulses of two kinds are kindled and rekindled: truly new ideas which are generated (cf. e.g. De Villiers 2002:16-21), and older, dormant ideas which are regenerated (i.e. typically Von Radian theology; cf. e.g. Von Rad 1960).

In this article two developments which are often thought of as new, but which indeed are not, are brought together in a way that ought to be more widely accepted, but the inherently overlapping characteristics and implicit possibilities of which have never in this way been made explicit:

- Pentateuch Theory, perhaps the most foundational of the exegetical enterprises (in the sense that, historically, when the understanding of the Pentateuch has changed, it has led to important adjustments in the other specialisms related to Biblical Studies and to major shifts, even rifts, within Christianity).

- Spirituality, which for our purposes here is focused on as Christian Spirituality (on the relationship between spirituality in general and Christian spirituality, cf. e.g. McGrath 1999:15), with the specific academic discipline of Biblical Spirituality as the main focal point.

\section{Pentateuch Theory: Old and new}

It is rather a strange twist, that denunciations from (usually) church circles of Pentateuch Theory, the critical and historical analysis of how the collection of 'Moses books' from Genesis to Deuteronomy came into being, would include the word 'new'. For those who express such 
denunciations, it may well be that they had themselves not encountered this analytical tradition through their catechetical and other church education courses, and therefore, for them, this would be a 'new' way of looking at the biblical texts. However, the lacunae in such church-based training simply hide what is indeed not new, but has been in existence for a long while. Another reason for the avoidance tendency with respect to historical criticism within church circles is that the uncertainty associated with such analyses are often experienced as being transferred to faith too. Whilst it is indeed true that ' $[w]$ e know that Moses did not write the Pentateuch. What we are less sure about, is precisely how Moses did not write the Pentateuch' (Lombaard 2009:2), this ought not to be cause for spiritual discomfort, but is, more appropriately, precisely the opposite: such a variety of possibilities is what safeguards Bible readers from repressive mono-spiritualities (cf. Craghan 1983:4-15).

Often, the main reference point to the beginnings of the 'new' historical-critical scholarship on the Old Testament, is Wellhausen, who particularly with his systematisation of the four authorial layers of the Pentateuch - namely at the hands of the Jahwist, Elohist, Deuteronomist and Priestly Writer - had been hugely influential on Old Testament scholarship (cf. e.g. Wellhausen 1963 [1877/1876]). However, Wellhausen's innovations were to offer a more coherent solution to problems which have until then long been realised and studied, but had thus far had poorer solutions. Wellhausen's contribution lies not in inventing a new method to answer new questions. Rather, he stood in a firm tradition, and contributed to it (cf. Smend 1989). To be sure, critical questions on the Pentateuchal contents had been asked within the church from its earliest times (cf. Houtman 1994:10-22), has through mission history been proven not to be an exclusively Western enterprise (Colenso 1862), and had had from these and other sources sustained scholarly contexts and developments (cf. e.g. Le Roux 1993 \& Kraus 1982).

However, Pentateuch Theory dates back even further than that, namely to the Pentateuch itself, which indicates in its texts its own understanding of its compositional history. In what he calls the Pentateuch's theory of the Pentateuch, Otto (2007:19-28, 2004:14-35; cf. Lombaard 2007:351-365) has made clear that the usual signs in the texts of the Pentateuch that had been interpreted by the scholars of modernity as accidental indications of different editorial activities at different times, had in fact been entirely deliberate activities by the scribes. These 'hands of Moses' had namely with full intent, for the sake of their readers, included references to other geographies and times in the text, and had drawn attention precisely to those 'fractures' in the text (in the language of Carr 1996) by the expressions used. In such ways, the Pentateuchal authors could indicate to their hearers that, for instance, the Mosaic laws are to be held in high esteem, in the authority of Moses, whereas the rest of their writings are clearly narratives from another time. This, the earliest readers were intended to, and would have, reflexively understood from the obvious narratological techniques employed. Unless one wants to underestimate the sophistication and the intellectual agility of the Pentateuchal authors and their intended readers, a conclusion pushes itself to the fore here: that the developmental stages of the material in the "Moses books" were made visible for all to see, from the very inception of the use of these laws and narratives in the text of the Pentateuch.

Whereas modern insights into these refined scribal techniques are thus relatively new, the acceptance of a layered, historical text of the Pentateuch goes back to the oldest possible time, namely to the time of the origination of the biblical text itself. Already in conveying their historical faith, the Pentateuch authors themselves were namely involved in conveying their understanding of the layered nature of the Pentateuchal material. This was done with clear theological intent: to stress to their readers the importance of the Mosaic legal material. It is precisely such an apologetic intent, or confessional purpose, which can be found with almost all writers on the historicalcritical matters of the text of the Pentateuch, throughout the centuries. The purpose was to explain, even to rescue the integrity of the biblical text, and the resultant faith, from the vagaries of the prominent questions of their time. In trying to explain contextually the inherent, underlying message of the biblical text, Pentateuch criticism has been doing nothing new, from its inception, until now.

\section{Biblical Spirituality: Old and new}

Although the academic discipline of Spirituality is a relatively recent concretisation of what had long been happening within the university (cf. Kourie 2009:148-173), the phenomenon of spirituality as an expression of the human species goes back as far as is humanly possible - to our very beginnings, with the very first expressions of the cultural alertness or the intellectual awareness of homo sapiens (Van Huyssteen 2006:217-325). It is fitting therefore that religion has from the very inception of the institution of the university been a part of its curriculum, a heritage which ought in principle and practice to remain so (Lombaard 2011b). With the growing openness towards Spirituality as an academic discipline, methodological reflection of the intellectual entanglement with such an engaging subject matter (e.g. Liebert 2002:30-49; Agnew 2008:187-197) has been developing (cf. e.g. Hense \& Maas 2011; Kourie 2009:159-166; Gräb 2008:9-19; Waaijman 2000:239-295) - however, not to universal satisfaction. In the search for more concrete and competing theories for the discipline (Lombaard 2010/2011) and for meta-theoretical grounding (Van den Hoogen 2011:115-176; Schreiber 2011), the quest for, respectively, practical applicability and philosophical depth continues.

With one section of the discipline of Spirituality, however, the development towards a workable model has been brisk: writers on Biblical Spirituality have been particularly diligent in this regard. This is understandable, for at least two reasons:

- The discipline is small, though growing, with relatively few researchers working directly in the field (indirectly, many theologians and social scientists working on 
the intersection between Bible and faith contribute to this field; hence such explorations as Lombaard 2011c, 2010:263-283). This enables an implicit, more or less commonly-shared search for a working model, certainly to a greater extent than is the case with vast numbers of competing perspectives in long-established, widelypopular academic disciplines.

- Most, if not all, the scholars in the field of Biblical Spirituality come from, or have a very strong earlier orientation to (e.g. Waaijman 2004, 1983), Old Testament or New Testament Studies and cognate fields (cf. Lombaard 2006a:909-929) - disciplines which are noted for their strong methodological traditions (Lombaard 2010/2011). Often, these scholars had become disillusioned because of the exegetical enterprise as it had developed not going far enough in drawing lines from the intellectual (cf. however De Villiers 2006:99-121) to include also the existential engagement with the biblical texts (cf. Lombaard 2006b:18-31). The transformative experience inherent to such engagements (e.g. Schneiders 2005:18-22; Agnew 2008:187-197; Waaijman 2000:129-187) is experienced as having been lost - something Biblical Spirituality as a discipline is explicitly given to recouping (Lombaard 2008:139-153). However, scholars in Biblical Spirituality have, along with this turn (or return) to the spiritual (cf. Kourie 2006:19-38), retained from their earlier research the sense of methodological discipline in making clear the outlines of the manner in which they engage exegetically and spiritually with ancient-text-in-modern-context (hyphenated, because it is methodologically unsound to divorce the 'then' from the 'now' - Le Roux 1997:410-416, 419).

For particularly the second reason, a somewhat structuralist model for Biblical Spirituality has evolved, though with one half of it dedicated to specifically the intensely experiential aspect of the triangular God-Bible-believer faith relationship (cf. Lombaard 2011a). The latter aspect will however always remain difficult to capture within a static description such as a working model of necessity has to be; this aspect can therefore at best only be indicated, and never really locked into such an intellectual depiction.
The model I draw on here is that developed in Lombaard (2008:139-153), in discussion with the work by authors such as Agnew (2008:187-197), Deist (1994), Eaton (2004), Nolan (1982), Rossouw (1963); and Schneiders (1999). Much of the history behind this reflective process is to be published together in a volume titled The Old Testament and Christian Spirituality (Lombaard 2011d), but may as a summary be presented differently in Figure 1.

It is clear from the aforementioned model that the academic discipline of Biblical Spirituality is constituted by two, interrelated aspects: an exegetical and an experiential aspect. These two aspects, respectively called 'Spiritualities reflected in the Bible' and 'Spiritualities that draw on the Bible' in the model, may be differently described: on the one hand, as analytical, historical and, in a sense, normative; on the other hand, as existential, contemporary and, in a sense, receptive. An inter-relation or interaction between these two aspects consists, both phenomenologically and theologically, therein that the texts from the ancient world foundationally influence the religious experience of their readers in the latter-day world. This may at first glance seem to be a one-way influence, but Reader Response Criticism (e.g. Stratton 1995:18-23) and Genitive Theologies (cf. e.g. Russell 1974:52-53), more broadly constituted as Hermeneutics (cf. Thiselton 1992), have taught us that this is certainly not so. The influence, deliberate or tacit, of the reader on what is seen in the text, what is taken from it, and in which ways this is done, confirms the exchange relationship of the ancient-Textmodern-context encounter of the reader.

In both aspects of the aforementioned model, the 'Spiritualities reflected in the Bible' and 'Spiritualities that draw on the Bible', the triangular God-Bible-believer faith relationship lies at the base of the spiritualities that find expression there, albeit in different ways. In the former, the mystery of the God-believer interaction gives rise to (what would in time become biblical) texts, in certain cases first to oral traditions that underlie the texts, and in many cases also to editorial activities of various sorts that result from the texts and contexts, and result in altered texts (the moment that the traditions or texts have been formulated, the third
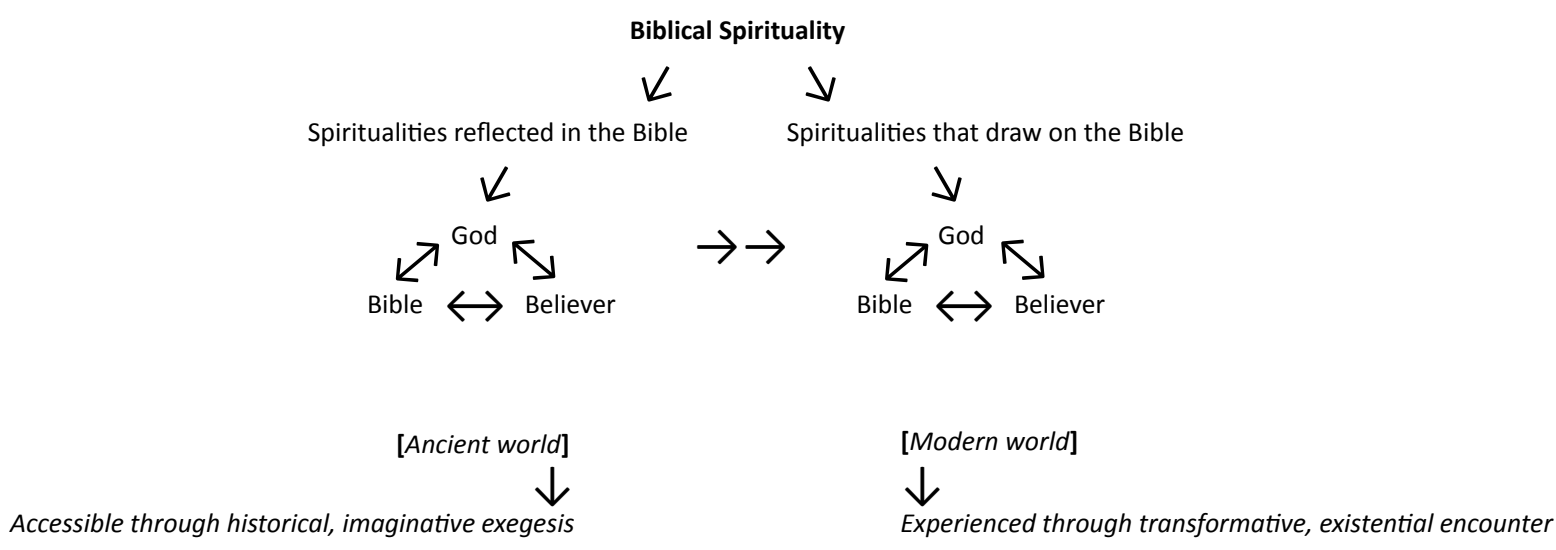

FIGURE 1: The discipline of Biblical Spirituality. 
part of this triangular relationship has been constituted). In the case of the 'Spiritualities that draw on the Bible' aspect, the mystery of the God-Bible-believer interaction is different from that just described, but not unrelated. The 'texts' being created are no longer those that in time would be canonised (be it informally or formally) as Scripture, but now readers draw on these authoritative texts (unstable as the concept of a biblical canon is, the normativity of the accepted Holy Texts need not be relented - cf. Lombaard 2011e:74-76) and on the influential interpretative traditions that go along with them, and go on to contribute to the interpretative universe by adding what Deconstructionism would label 'traces' (cf. Derrida 1976), or Semiotics would label 'signs' (cf. Peirce 1976 [1894]:353-359), or Dawkinsian analysis would label 'memes' (cf. Dawkins 1976). In engaging with the text, the readers thus come to contribute to the engagement with the text of those who will read next. Reading means that meaning grows.

That there is between these two aspects of the model broad parallels in the God-Bible-believer interaction, but not plain duplication, should by now be evident. Furthermore, calling this interaction a 'mystery' has to do not only with the God-human encounter, which in traditional social-scientific thinking would lie beyond acceptable frames of scholarly reference, yet which in mainstream theological thinking has been fundamentally constitutive of most spiritualities and of religion. This mystery concerns also the very concrete historical factors involved, which are however so complex and changeable, or dynamic, as always to lie beyond firm grasp and static description. 'Mystery' here therefore refers to an openness (Waaijman 2004:10-12) which is constitutive of all human experience, whether viewed from social-scientific or from theological perspective.

It must therefore be understood with this model that what may be presented here in broad outline, can never truly be pinpointed with precision: in both ancient and modern worlds, the God-Bible-believer faith triangle is existentially too intangible, sociologically too entangled, and psychologically too changeable (or dynamic) to be captured with certainty in such a static schematic representation. This graphic representation above therefore has more of a metaphoric value, rather than a precisely descriptive value. Yet this representation is not without merit, in that it attempts to concretise pictorially what the discipline of Biblical Spirituality has been striving towards verbally. As with any artist's impression of a developing architectural project, the model is not the real thing; at best, the model alludes strongly to its point of reference, but can offer no more than a metaphor in scale.

The imprecision, or the metaphoric nature, of this representation is therefore apt in this sense, then, that in this very respect it reflects best what is - again - the mystery of the divine encounter in relation to the Scriptures (cf. Waaijman 2004). The thoroughly human, utterly historically codetermined nature of the God-Bible-believer triangle which finds reflection in what the Holy Texts in time came to be, is mirrored, though unevenly, by the thoroughly human, utterly historically codetermined nature of the GodBible-believer triangle which results from reflection on what the Holy Texts have come to say. Old and new meet, in an ancient-Text-in-modern-context encounter.

This spirituality of engagement with a holy text, in order to explicate its inherent meaning whilst at the very same time indicating a derived, applicatory meaning for the reader's context, goes back to the early post-exilic, that is, Second Temple period in ancient Israel's history, as reflected in Nehemiah 7:72b-8:18 (cf. Lombaard 2010/2011). This remains throughout the subsequent two and a half millennia a fundamental constitutive aspect of much biblical interaction, up to and including our time (Berlinerblau 2005). The old had made the new; in the new, the old is made to live on.

\section{Old and new: The mystifying 'mosaic of Moses' and Biblical Spirituality}

In the previous two points, on Pentateuch Theory and on Biblical Spirituality, remarkable parallels present themselves. In both these fields, what is often experienced as new is in fact so old, going back to the earliest possible respective beginnings, as to be foundationally constitutive to the discipline. In both fields, historical and theological contents mix almost inextricably, not only during the coming into being of the respective dynamics concerned, but also throughout the history of influence that results from it. In both these fields, apologetics or confession can be discerned as inherent to the earliest impulses towards the respective dynamics, which has continued throughout subsequent history, and still remains an active ingredient of these dynamics. Such dynamics include - drawing here on Rossouw (1963) - the exegetically-and-existentially engaging awareness that, in the reading of the Text, the reader is himself or herself being read; differently put: in engaging with the biblical material, readers find themselves engaged; yet differently formulated: in interpreting the words of the Word, readers find themselves interpreted. This awareness of finding oneself being interpreted, being engaged, being read, namely reciprocally as one encounters the Text, is experienced in such a thoroughgoing way by the recipients as to find their being taken up, redefined, transformed by the event; which may be experienced, alternatively, as: by the Bible; which may yet again be experienced, alternatively, as: by the Divine. This is nothing less than dialogical mysticism (cf. Waaijman 2004:18-20).

\section{Acknowledgements Competing interests}

The author declares that he has no financial or personal relationship(s) which may have inappropriately influenced him in writing this article.

\section{References}

Agnew, U., 2008, 'Transformative reading', in U. Agnew, B. Flanagen \& G. Heylin (eds.), 'With wisdom seeking God': The academic study of spirituality, pp. 187-197, Peeters, Louvain. 
Berlinerblau, J., 2005, The secular Bible: Why nonbelievers must take religion seriously, Cambridge University Press, New York, NY.

Carr, D.M., 1996, Reading the fractures of Genesis: Historical and literary approaches, Westminster John Knox Press, Louisville, KY.

Coblentz Bautch, K.N., 2010, How videoconferencing with international scholars can enliven your classroom, viewed 18 July 2011 from www.sblsite.org/assets/pdfs/ KCB_IClvideoconferencing.pdf

Colenso, J.W., 1862, The Pentateuch and book of Joshua, Longman, London.

Comte-Sponville, A., 2007, The little book of atheist spirituality, Viking, London.

Comte-Sponville, A. 2006, L'esprit de l'athéisme: Introduction à une spiritualité sans Dieu [The spirit of atheism: Introduction to a spirituality without God], Albin Michel, Paris.

Craghan, J., 1983, Love and thunder: A spirituality of the Old Testament, Liturgical Press, Collegeville, PA.

Dawkins, R., 1976, The selfish gene, Oxford University Press, New York, NY.

Deist, F., 1994, Ervaring, rede en metode in Skrifuitleg: 'n Wetenskapshistoriese ondersoek na Skrifuitleg in die Ned. Geref. Kerk 1840-1990 (RGN-Studies in metodologie), Die RGN-Uitgewers, Pretoria.

Derrida, J., 1976, Of grammatology, Johns Hopkins University Press, Baltimore, MD.

De Villiers, E., 2002, 'Who will bear moral responsibility?' Communicatio 28(1), 16-21. http://dx.doi.org/10.1080/02500160208537953

De Villiers, P.G.R., 2006, 'Spirituality, theology and the critical mind', in P.G.R. de Villiers, C.E.T. Kourie \& C. Lombaard (eds.), The Spirit that moves: Orientation and issues in spirituality (Acta Theologia suppl. 8), pp. 99-121, University of the Free State Press, Bloemfontein.

Du Toit, C.W. \& Mayson, C.P. (eds.), 2006, Secular spirituality as a contextual critique of religion, Research Insitute for Theology and Religion, University of South Africa, Pretoria.

Eaton, J., 2004, Meditating on the Psalms, Westminster John Knox Press, Louisville, KY

Gräb, W., 2008, 'Individualisierung - Spiritualität - Religion: Transformationsprozesse auf dem religiösen Feld in interdisziplinärer Perspektive', in W. Gräb \& L. Charbonnier (Hrsg.), Individualisierung - Spiritualität - Religion, pp. 9-19, LIT Verlag, Berlin.

Hense, E. \& Maas, F., 2011, Towards a theory of Spirituality (Studies in Spirituality suppl. 22), Peeters, Louvain.

Houtman, C., 1994, Der Pentateuch: Die Geschichte seiner Erforschung neben einer Auswertung, Kok Pharos, Kampen.

Kourie, C., 2009, 'Spirituality and the university', Verbum et Ecclesia 30(1), 148-173.

Kourie, C., 2006, 'The "turn" to spirituality', in P.G.R. de Villiers, C.E.T. Kourie \& C. Lombaard (eds.), The Spirit that moves: Orientation and issues in spirituality (Acto Theologia suppl. 8), pp. 19-38, University of the Free State Press, Bloemfontein.

Kraus, H.-J. 1982, Geschichte der historisch-kritischen Erforschung des Alten Testaments, 3, erw. Aufl., Neukirchener Verlag, Neukirchen-Vluyn.

Le Roux, J.H., 1997, 'Our historical heritage', Old Testament Essays 10(3), 401-423.

Le Roux, J.H., 1993, A story of two ways: Thirty years of Old Testament scholarship in South Africa, Old Testament Essays, suppl. 2, Verba Vitae, Pretoria.

Liebert, E., 2002, 'The role of practice in the study of Christian Spirituality', Spiritus 2(1), 30-49. http://dx.doi.org/10.1353/scs.2002.0011

Lombaard, C., 2011a, 'Christo Lombaard gee sy mening oor die Jesus Seminaar', Litnet Akademies 8/1, Maart 2011, besigtig 20 Junie 2011, by www.litnet.co.za/cgi-bin/ giga.cgi?cmd=cause_dir_news_item \&cause_id $=1270 \&$ news_id $=104432 \&$ cat_ id=166

Lombaard, C., 2011b, 'Having faith in the university? Aspects of the relationship between religion and the university', in R. Venter (ed.), Faith, religion and the public university, Acta Theologica, suppl. 14, 49-65.

Lombaard, C., 2011c, 'Biblical Spirituality, and JH Eaton', Verbum et Ecclesia, working paper.

Lombaard, C., 2011d, The Old Testament and Christian Spirituality. Collected Methodological Essays. South African and General Perspectives (International Voices in Biblical Studies). Society of Biblical Literature, Atlanta, GA (forthcoming)

Lombaard, C., 2011e, 'Biblical Spirituality and human rights', Old Testament Essays 24(1), 74-93.

Lombaard, C., 2010/2011, 'Biblical Spirituality and interdisciplinarity', 'Claiming Conceptual Space. Reimagining the Study of Religion and Theology: Changing Contexts and Social Discourses' proceedings, Huguenot College, Wellington, 0610 April 2010
Lombaard, C., 2010, 'Betwixt text and nature, God and evolution: Biblical reception and creationism at the Creation Museum in cultural-anthropological perspective', Tydskrif vir Semitistiek/Journal for Semitics 19(1), 263-283.

Lombaard, C., 2009, 'Two approaches to life in the Second Temple Period: Deuteronomy and Qoheleth', HTS Teologiese Studies/Theological Studies 65(1) Art. \#185, 4 pages. http://dx.doi.org/10.4102/hts.v65i1.185

Lombaard, C., 2008, 'What is Biblical Spirituality? - Perspectives from a minor genre of Old Testament scholarship', in H. Blommestijn, C. Caspers, R. Hofman, F. Mertens, P. Nissen, \& H. Welzen (eds.), Seeing the seeker: Explorations in the discipline of Spirituality (Festschrift for Kees Waaijman; Studies in Spirituality, suppl. 19), pp. Spirituality (Festschrift for Ke
139-153, Peeters, Louvain.

Lombaard, C., 2007, 'Of serpents, reeds, understanding, and turns: Some perspective on implied apologetics and Pentateuch theory', Studia Historiae Ecclesiasticae XXXIII(1), 351-365

Lombaard, C., 2006a, 'Four recent books on spirituality and the Psalms: Some contextualising, analytical and evaluative remarks', Verbum et Ecclesia 27(3), contextualisi

Lombaard, C., 2006b, 'The Old Testament between diachrony and synchrony: Two reasons for favouring the former', Journal for Semitics/Tyskrif vir Semitistiek 15(1), $18-31$.

McGrath, A.E., 1999, Christian Spirituality: An Introduction, Blackwell Publishers, Oxford.

Nolan, A., 1982, Biblical Spirituality, The Order of Preachers (Southern Africa), Springs.

Otto, E., 2007, 'A hidden truth behind the text or the truth of the text: At a turning point of biblical scholarship two hundred years after De Wette's dissertatio critico exegetica', in J. le Roux \& E. Otto (eds.), The Pentateuch between diachrony and synchrony, pp. 19-28, T\&T Clark International, New York, NY.

Otto, E., 2004, 'The Pentateuch in synchronical and diachronical perspectives: Protorabbinic scribal erudition mediating between Deuteronomy and Priestly Code', in E. Otto \& R. Achenbach (Hrsg.), Das Deuteronomium zwischen Pentateuch und Deuteronomistischem Geschichtswerk, pp. 14-35, Vandenhoeck \& Ruprecht, Göttingen.

Peirce, C.S., 1976 [1894], 'How to reason: A critick of arguments', in C. Eisele (ed.) The new elements of mathematics, pp. 353-359, Mouton Publishers, The Hague.

Rossouw, H.W., 1963, Klaarheid en interpretasie: Enkele probleemhistoriese gesigspunte in verband met die leer van die duidelikheid van die Heilige Skrif, Drukkerij en uitgeverij Jacob van Campen N.V., Amsterdam.

Russell, L.M., 1974, Human liberation in a feminist perspective - A theology, John Knox Press, Westminster.

Salzberg, S., 2002, Faith: Trusting your own deepest experience, Element, London.

Smend, R., 1989, Deutsche Alttestamentler in drei Jahrhunderten, Vandenhoeck \& Ruprecht, Göttingen.

Schneiders, S., 2005, 'Biblical foundations of spirituality', in E.J. Mahoney (ed.), Scripture as the soul of theology, pp. 1-22, Liturgical Press, Collegeville, PA

Schneiders, S., 1999, The revelatory text: Interpreting the New Testament as sacred scripture, Liturgical Press, Collegeville, PA.

Schreiber, D.A., 2011, 'On the epistemology of postmodern spirituality', Verbum et Ecclesia, working paper.

Stratton, B.J., 1995, Out of Eden: Reading, rhetoric, and ideology in Genesis 2-3, Sheffield Academic Press, Sheffield.

Thiselton, A.C., 1992, New horizons in hermeneutics, Zondervan, Grand Rapids, MI.

Van den Hoogen, T., 2011, A Taste of God: On Spirituality and reframing Foundational Theory (Nijmegen Studies in Theology), LIT Verlag, Münster.

Van Huyssteen, J.W., 2006, Alone in the world? Human uniqueness in science and theology, William B. Eerdmans Publishing Company, Grand Rapids, MI.

Von Rad, G., 1960, Theologie des Alten Testaments, Chr. Kaiser Verlag, München.

Waaijman, K., 2004, Mystiek in de Psalmen, Uitgeverij Ten Have, Baarn.

Waaijman, K., 2000, Handbuch der Spiritualität: Band 2: Grundlagen, MatthiasGrünewald-Verlag, Mainz.

Waaijman, K., 1983, Psalmen over de uittocht, Uitgeversmaatschappij J.H. Kok, Kampen.

Wellhausen, J., 1963 [1877/1876], De composition des Hexateuchs und der historischen Bücher des Alten Testaments, 4. Auflage, De Gruyter, Berlin. 